\title{
OBITUARIES
}

Obituaries should be submitted by email to Laura Pacey at I.pacey@nature.com.

All submitted obituaries should be 450 words maximum in length (apart from obituaries for

past presidents of the BDA where the length should be 800 words).

Content of the obituary is down to the individual author, and the approval of the family should

be given for the obituary prior to submission to the $B D J$.

\section{THOMAS CHARLES ROWBOTHAM}

\section{1-2014}

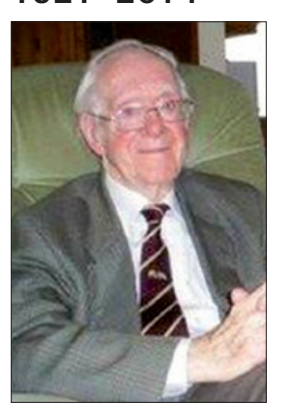

outbreak of the Second World War. Following graduation in 1944 (as joint top of his year) he was conscripted into the Royal Army Dental Corps and attained the rank of Captain.

On demobilisation he joined the full time teaching staff at his old school, but subsequently opened his own dental practice, although he never gave up his teaching commitments, being interested in the training of all members of the dental team. It was this interest that drew him back to full time teaching in the dental school in the 1970s when he established an undergraduate clinic featuring low seated, close support clinical work - a novelty in undergraduate teaching at the time.

He co-authored (with fellow teachers in Manchester, Colin Cooke and Donald Cartledge) a series of scientific articles on the management of dental traumatic injuries to anterior teeth, being amongst the earliest of such reviews in the British dental literature. He remained fascinated by the recuperative properties of the adolescent dental pulp. He also contributed to a book on Romano-British remains found in York with observations on early British dental techniques.

He is survived by Irene, his beloved wife of 68 years, his son, Ian, (two sons, John and Colin sadly predeceased him), his daughters-in-law and grandchildren, to whom we extend our sincere sympathy.

John D. Lilley and Gordon A. Smith

\section{TOM PEIRSON}

trait photographer/shopkeeper and a schoolmistress, and was brought up in Burton in what was then Westmorland. By the age of ten he had lost the end of a finger having jammed it in his air rifle when shooting rats from the stable roof. He attended Heversham School showing not only academic ability but also practical skills; thus dentistry seemed an appropriate career and he started studies at the Turner Dental School in Manchester just before the

\section{9-2014}

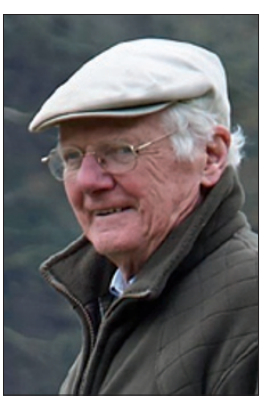

something more adventurous in life, Tom successfully applied for a posting to the Aden Protectorate, where he spent the subsequent 18 months providing dental treatment to the local community in sometimes challenging circumstances. On one occasion, whilst assisting a surgeon with an amputation, Tom found himself having to complete the operation when the surgeon became too weak owing to an attack of malaria. He was also fortunate to survive a plane crash whilst flying close to the border area. Missing Jill, his future wife, Tom wrote her a letter asking her to marry him, resulting in Jill jumping on the first plane to Aden!

Following Aden, Tom bought a practice in Callington, Cornwall, where he spent the following 30 years offering NHS dental treatment to appreciative patients in the area.

During this time Tom was an active member of the Local Dental Committee, the GDSC, the Plymouth section of the BDA and Western Counties Branch, and served as Branch Steward of the BDA Benevolent Fund for many years.

No exchange with dental colleagues in the city of Brest was complete without the memorable contribution Tom brought to these occasions.

In 1991 Tom was awarded Life Membership of the BDA. He was also a founder member of Callington Rotary Club.

After his retirement in 1990, Tom continued to pursue an active life in country sports and his hobby of woodturning. Tom sadly passed away on 17 March 2014.

Tom is greatly missed by his wife, Jill, daughters Victoria and Bridget and many friends and colleagues.

John Turner 